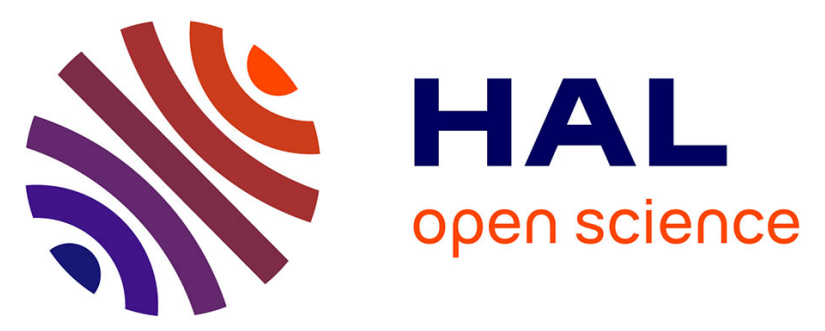

\title{
Differences in behavioural traits among native and introduced colonies of an invasive ant
}

\author{
Olivier Blight, Roxana Josens, Cleo Bertelsmeier, Silvia Abril, Raphaël
}

Boulay, Xim Cerda

\section{To cite this version:}

Olivier Blight, Roxana Josens, Cleo Bertelsmeier, Silvia Abril, Raphaël Boulay, et al.. Differences in behavioural traits among native and introduced colonies of an invasive ant. Biological Invasions, 2017, 19 (5), pp.1389-1398. 10.1007/s10530-016-1353-5 . hal-01791001

HAL Id: hal-01791001

https://hal-univ-avignon.archives-ouvertes.fr/hal-01791001

Submitted on 14 May 2018

HAL is a multi-disciplinary open access archive for the deposit and dissemination of scientific research documents, whether they are published or not. The documents may come from teaching and research institutions in France or abroad, or from public or private research centers.
L'archive ouverte pluridisciplinaire $\mathbf{H A L}$, est destinée au dépôt et à la diffusion de documents scientifiques de niveau recherche, publiés ou non, émanant des établissements d'enseignement et de recherche français ou étrangers, des laboratoires publics ou privés. 


\title{
Differences in behavioural traits among native and introduced colonies of an invasive ant
}

\author{
Olivier Blight • Roxana Josens • Cleo Bertelsmeier • \\ Silvia Abril · Raphaël Boulay $\cdot$ Xim Cerdá
}

\begin{abstract}
Identifying the factors that promote the success of biological invasions is a key pursuit in ecology. To date, the link between animal personality and invasiveness has rarely been studied. Here, we examined in the laboratory how Argentine ant populations from the species' native and introduced ranges differed in a suite of behaviours related to species interactions and the use of space. We found correlations among specific behavioural traits that defined an explorative-aggressive syndrome. The Main "European" supercolony (introduced range) more readily explored novel environments, displayed more aggression, detected food resources more quickly, and occupied more space than the Catalonian supercolony (introduced range) and two other Argentine
\end{abstract}

\section{O. Blight $(\bowtie) \cdot X$. Cerdá}

Estación Biológica de Doñana, Consejo Superior de Investigaciones Científicas, 41092 Seville, Spain

e-mail: olivier.blight@imbe.fr

\section{R. Josens}

Facultad de Ciencias Exactas y Naturales, Universidad de Buenos Aires, IFIBYNE, CONICET, Buenos Aires, Argentina

\section{Bertelsmeier}

Department of Ecology and Evolution, University of Lausanne, Le Biophore, UNIL-Sorge, 1015 Lausanne, Switzerland

\section{S. Abril}

Department of Environmental Sciences, University of Girona, 17071 Girona, Spain supercolonies (native range). The two native supercolonies also differed in their personalities; one harbouring the less invasive personality, while the other is intermediate between the two introduced supercolonies. Therefore, instead of a binary pattern, Argentine ant supercolonies display a behavioural continuum that is independent on their geographic origin (native/introduced ranges). Our results also suggest that variability in personality traits is correlated to differences in the ecological success of Argentine ant colonies. Differences in group personalities may facilitate the persistence and invasion of animals under novel selective pressures by promoting adaptive behaviours. We stress that the concept of

\footnotetext{
R. Boulay

IRBI, UMR CNRS 7261, Université François Rabelais de Tours, 37200 Tours, France

Present Address:

O. Blight

Institut Méditerranéen de Biodiversité et d'Ecologie, Avignon Université, UMR CNRS IRD Aix Marseille Université, Avignon, France
} 
animal personality should be taken into account when elucidating the mechanisms of invasiveness.

Keywords Animal personality - Behavioural syndrome $\cdot$ Supercolony $\cdot$ Invasive ant

\section{Introduction}

The introduction of non-native species to a previously unoccupied region is considered to be a key threat to the integrity of many natural habitats and ecosystems worldwide, driving loss of biodiversity (Clavero and García-Berthou 2005). Among the pool of species that are transported outside their native range, a small subset is able to establish and spread, leading to major modifications in ecosystem functioning (Simberloff et al. 2013). Identifying the traits that promote the success of invasive species is therefore a key pursuit in ecology.

Differences in success not only among species but also among different populations within a single species (Fogarty et al. 2011) suggest that multiple traits may influence species' invasion success. These traits can be a pre-adaptation of a population (e.g. high productivity) or be developed and expressed after the introduction. Evolutionary processes such as genetic drift resulting from bottlenecks (Tsutsui et al. 2000) or new selection pressures (Giraud et al. 2002) contribute also to changes in important traits (Mooney and Cleland 2001; Sakai et al. 2001), such as social organisation and competitive abilities (Holway and Suarez 1999).

Recent studies suggest animal personality (i.e., inter-individual behavioural differences that are consistent over time and across different contexts) and behavioural syndromes (i.e., suites of correlated behaviours consistent across contexts) can provide novel insights into biological invasions (Wolf and Weissing 2012). Inter-individual variation within species could result in differential abilities manifesting themselves at each invasion stage, thus allowing certain individuals to invade and impact ecosystems (Chapple et al. 2012). Such traits like sociality, boldness, or activity have been proposed as related to the invasion process (Sih et al. 2004; Pintor et al. 2008; Chapple et al. 2012; Wolf and Weissing 2012; Carere and Gherardi 2013). For example, high boldness and exploratory activity may enhance the likelihood of being transported to and dispersing in a new habitat (Cote et al. 2010). By comparing the personality of different individuals of an invasive species in their native and introduced ranges, it may be possible to shed new light on the factors that promote invasion success (Carere and Gherardi 2013). However, such comparisons are uncommon, particularly in group-living species.

Variation in group personalities has recently been described in many non-invasive species including fish (Dyer et al. 2009), birds (Aplin et al. 2013, 2014), and insects: ants (Chapman et al. 2011; Gordon et al. 2011; Pinter-Wollman et al. 2012; Scharf et al. 2012; Bengston and Dornhaus 2014; Hui and Pinter-Wollman 2014; Kleeberg et al. 2014; Modlmeier et al. 2014; Blight et al. 2016); bees and bumble bees (Wray et al. 2011; Wray and Seeley 2011); and spiders (Keiser et al. 2014; Pruitt and Keiser 2014) (reviewed in Jandt et al. 2014 and Kralj-Fišer and Schuett 2014). In social species, personality traits are expressed at both the individual- and group-level (Jandt et al. 2014) and can affect the efficiency of group-level processes and performance (Webster and Ward 2011). For instance, in the gypsy ant Aphaenogaster senilis, proactive colonies that contained bold individuals who more readily explored novel environments, exhibited aggressive behaviours and demonstrated higher foodretrieval efficiency during intraspecific competition trials (Blight et al. 2016). Group personality is also related to differences in collective foraging in social spiders (Wright et al. 2015). As a consequence, we might expect group-level personality traits to be related to invasiveness in invasive social species (Fogarty et al. 2011).

The Argentine ant (Linepithema humile) provides a good example of the invasion success of a social species. This invader has successfully spread across the globe in regions with Mediterranean and subtropical climates, through the intensification of human activities over the last century (Suarez et al. 2001). The Argentine ant is one of the most devastating invaders in the world (Holway et al. 2002), as attested by its registration on the ' 100 of the world's worst invasive alien species' list (Lowe et al. 2000). Interestingly, in its introduced range, the Argentine ant often forms a single geographically vast supercolony-large networks of integrated polygynous (multiple queens) nests exhibiting no aggression 
within supercolonies but high aggression between supercolonies (Helanterä et al. 2009)—that dominates several smaller supercolonies.

Considering its biology and invasiveness, L. humile represents an ideal species model to investigate personality traits in invasive social species. In the current study, we investigated using a series of individual- and group-level behavioural tests, if supercolonies of Argentine ants from the introduced range (Spain) differ from those of the native range (Argentine) in a suite of behaviours: aggression, exploratory activities, and spatial distribution.

\section{Materials and methods}

\section{Colony collection and maintenance}

In May 2014, we sampled two Argentine ant supercolonies in the species' native range (Buenos Aires, Argentine) [we were allowed to import to Spain only two boxes of Argentine ants (import license 09 April 2014 from the Spanish Ministry of Agriculture, Food, and the Environment)]. The supercolonies (hereafter BA1 and BA2) were located $1 \mathrm{~km}$ apart. At the same time (May 2014), we also sampled two supercolonies in the species' introduced range: the Main European supercolony (hereafter the MAIN supercolony) in Doñana National Park (Huelva, SW Spain) and the Catalan supercolony (hereafter the CATA supercolony) at Caldes d'Estrac (Barcelona, NE Spain). We sampled two locations separated from at least $500 \mathrm{~m}$ of both introduced supercolonies. The MAIN supercolony is one of the world's most successful invasive populations; its members have been transported and established at least in the USA, Europe, Japan, Australia, and South Africa (Vogel et al. 2010). This supercolony dominates other supercolonies of $L$. humile that are restricted to small areas (Thomas et al. 2006; Brandt et al. 2009; van Wilgenburg et al. 2010). This is the case in Europe where the Catalonian supercolony is restricted to a small region in eastern Spain whereas the MAIN supercolony spans for thousands of kilometres in southern Europe (Giraud et al. 2002; Blight et al. 2012). Fragments from these four supercolonies were set up in artificial nests $(30 \times 15 \times 6 \mathrm{~cm})$ in the Doñana Biological Station and kept in a climate chamber (Aralab, Fitoclima 5000; $\left.25 \pm 1{ }^{\circ} \mathrm{C}, 50 \pm 10 \% \mathrm{RH}\right)$. They were fed the same diet (honey and meal worms) and given water ad libitum. All behavioural experiments were conducted at room temperature $\left(26 \pm 1{ }^{\circ} \mathrm{C}\right)$ in June 2014.

Bioassays

1. Aggressiveness towards allospecifics We randomly collected five $L$. humile workers and put them in a Petri dish $(\varnothing 5.5 \mathrm{~cm})$. After $2 \mathrm{~min}$, we introduced an Aphaenogaster senilis worker. Aphaenogaster senilis is a subordinate species native to Spain. All the A. senilis workers used in the trials came from the same colony, which had been collected in Doñana National Park in an area that has not yet been invaded by L. humile. The behaviour of the resident $L$. humile workers towards the introduced A. senilis worker was monitored for $3 \mathrm{~min}$ and classified as: (1) touch; (2) avoidance; (3) open mandibles; and (4) fighting. For each encounter, we calculated an aggression index, which was the number of aggressive acts (classes 3 and 4) divided by the number of peaceful interactions (classes 1 and 2). We conducted ten replicates per $L$. humile supercolony using each time naïve individuals. The Petri dish was cleaned between each trial.

2. Aggressiveness towards conspecifics We assessed intraspecific aggression by staging pairwise oneon-one confrontations in plastic petri dishes $(\varnothing 5.5 \mathrm{~cm})$ using ants from each of the three other L. humile supercolonies. We recorded during a 5-min period which ant initiated and/or won the fight (an ant "won" when it injured or killed its opponent). We conducted six replicates per supercolony pair using each time naïve individuals. To identify individuals during the trials, we collected from the same colony half-time individuals with a large gaster (fed with honey) and halftime individuals with a small gaster (unfed). The Petri dish was cleaned between each trial.

3. Exploration We placed 150 workers, 1 queen, and a batch of larvae in a box $(\varnothing 4 \times 10 \mathrm{~cm})$ containing moist cotton. After $30 \mathrm{~min}$ of acclimation, the ants were allowed access to a novel environment, which comprised a row of five circular chambers that were interconnected in series $(\varnothing 4 \times 10 \mathrm{~cm})$. We noted the farthest chamber visited by the ants during a 10-min period and the total number of 
ants in the chambers at the end of those $10 \mathrm{~min}$. The ants were then returned to the box awaiting the foraging activity test to begin. We conducted five replicates per supercolony using each time naïve individuals. The chambers were cleaned at the end of the test.

4. Foraging activity Thirty minutes after the exploration trials, we put honey in the centre of the third chamber and allowed ants access to the chambers. We recorded the time they took to detect the food and the total number of workers in the chamber over a 15 -min period.

5. Spatial brood and queen distribution We connected three glass tubes $(\varnothing 2 \times 10 \mathrm{~cm})$ containing water and covered by red paper to a circular arena $(\varnothing 10 \times 10 \mathrm{~cm})$. Five hundred workers, five queens, and a batch of larvae were placed in the arena and allowed to settle in one tube while the other two tubes were closed. After $48 \mathrm{~h}$, we opened them and monitored whether the workers transported queens and larvae to the new tubes at day +1 , day +5 , day +10 , day +24 , and day +30 . We conducted five replicates per supercolony using each time naïve individuals.

\section{Statistical analysis}

General linear models (GLMs) were used to determine whether the nine behavioural variables (1) aggressiveness towards allospecifics (bioassay 1); (2) fight initiation; and (3) fight success (bioassay 2); (4) exploration of a novel environment; (5) number of chambers explored (bioassay 3); (6) time to food detection; (7) level of foraging activity (bioassay 4); (8) distribution of queens; (9) distribution of larvae (bioassay 5); differed among the four supercolonies. GLMs 1-7 were fitted using Poisson or quasi-Poisson distributions, while GLMs 8 and 9 were fitted using a binomial distribution.

To identify suites of correlated behaviours, we performed a Principal Component Analysis (PCA). The PCA was performed to build synthetic variables (components of the PCA) summarising the nine behavioural variables. The variables included in the PCA were the average of the behavioural scores for each supercolony. Because the nine variables differed in their units (e.g. number of individuals or time in seconds), we normalised the data using the option "scale $=$ TRUE" of the prcomp function. We also calculated Spearman correlation coefficients between the behavioural scores for the experiments conducted on the same individuals (i.e. tests 4, 5, 6 and 7). All statistics were carried out using R (R Core Team).

\section{Results}

Ants from the MAIN supercolony were systematically the most aggressive. During allospecific encounters, MAIN ants were more aggressive than CATA (z= 5.04; $\quad P=0.0001), \quad$ BA1 $\quad(\mathrm{z}=4.04$; $P=0.0001)$, and BA2 $(\mathrm{z}=3.29 ; P=0.005)$, but the latter three did not differ significantly $(P>0.05)$ (Tables 1, 2). Moreover, during the intraspecific pairwise encounters, MAIN ants initiated significantly more fights $(71 \pm 7)$ than CATA $(38 \pm 10)$ $(\mathrm{z}=3.17 ; P=0.008)$ and BA1 $(38 \pm 7)(\mathrm{z}=2.61$; $P=0.04)$ ants, but not BA2 ants $(54 \pm 10)(\mathrm{z}=0.51$; $P=0.95$ ) (Tables 1,2$)$. The proportion of fights won by the different colonies did not differ $(P>0.05)$.

MAIN ants also displayed the most exploratory behaviour (MAIN: $89 \pm 5$ individuals -CATA: $55 \pm 4$ individuals; $\mathrm{z}=6.51, P=0.0001$; MAINBA1: $55 \pm 1$ individuals; $\mathrm{z}=5.07, P=0.0001$; MAIN-BA2: $69 \pm 1$ individuals; $\mathrm{z}=2.94, P=$ 0.02 ), although the supercolonies did not differ in the number of chambers visited $(P>0.05)$. Similarly, Main ants were the most active during foraging (i.e. the number of ants out of the nest over a $15 \mathrm{~min}$ period) with the BA2 ants (MAIN: $87 \pm 7$ individuals-BA2: $87 \pm 4$ individuals; $\mathrm{z}=0.08, P=0.99$; MAIN-CATA: $\quad 70 \pm 3$ individuals; $\mathrm{z}=4.32$, $P=0.0001 ; \quad$ MAIN-BA1: $69 \pm 2$ individuals; $\mathrm{z}=3.76, P=0.0001)$. They also detected the food resource more rapidly than all other supercolonies (MAIN: $233 \pm 40 \mathrm{~s}-$ CATA: $555 \pm 32 \mathrm{~s} ; \mathrm{z}=6.51$, $P=0.0001 ; \quad$ MAIN-BA1: $572 \pm 32 \mathrm{~s} ; \mathrm{z}=5.07$, $P=0.0001 ; \quad$ MAIN-BA2: $363 \pm 22 \mathrm{~s} ; \mathrm{z}=2.94$, $P=0.02)$. Finally, MAIN ants scattered the larvae significantly more than CATA $(\mathrm{z}=3.92$, $P=0.0001)$ and BA1 ants $(\mathrm{z}=4.24, P=0.0001)$ but not BA2 ants $(\mathrm{z}=2.1, P=0.15)$ (Tables 1,2$)$. There was no difference in the distribution of the five queens $(P>0.05)$.

The PCA revealed a behavioral syndrome described by two components that accounted for $87 \%(\mathrm{PC} 1)$ and $8 \%(\mathrm{PC} 2)$ of the total variance in the 
Table 1 Values (mean \pm SE) obtained from behavioural experiments using native and introduced Argentine ant supercolonies

\begin{tabular}{|c|c|c|c|c|}
\hline \multirow[t]{2}{*}{ Behaviour } & \multicolumn{2}{|l|}{ Native range } & \multicolumn{2}{|c|}{ Introduced range } \\
\hline & BA1 & BA2 & CATA & MAIN \\
\hline Interspecific aggression $^{1}$ & $0.90 \pm 0.07^{\mathrm{a}}$ & $1.46 \pm 0.37^{\mathrm{a}}$ & $1.10 \pm 0.16^{\mathrm{a}}$ & $3.74 \pm 0.40^{\mathrm{b}}$ \\
\hline Intraspecific fights initiated $^{2}$ & $38 \pm 10^{\mathrm{a}}$ & $54 \pm 10^{\mathrm{ab}}$ & $38 \pm 7^{\mathrm{a}}$ & $71 \pm 7^{\mathrm{b}}$ \\
\hline Intraspecific fights won ${ }^{3}$ & $25 \pm 9^{\mathrm{a}}$ & $29 \pm 9^{\mathrm{a}}$ & $10 \pm 4^{\mathrm{a}}$ & $29 \pm 7^{a}$ \\
\hline Exploratory activity ${ }^{4}$ & $55 \pm 1^{\mathrm{a}}$ & $69 \pm 1^{\mathrm{b}}$ & $55 \pm 4^{\mathrm{a}}$ & $89 \pm 5^{c}$ \\
\hline Chambers visited $^{5}$ & $3.4 \pm 0.2^{\mathrm{a}}$ & $3.6 \pm 0.2^{\mathrm{a}}$ & $3.3 \pm 0.3^{\mathrm{a}}$ & $4.1 \pm 0.3^{\mathrm{a}}$ \\
\hline Food detection ${ }^{6}$ & $572 \pm 108^{\mathrm{a}}$ & $363 \pm 22^{\mathrm{b}}$ & $558 \pm 32^{\mathrm{a}}$ & $233 \pm 40^{\mathrm{c}}$ \\
\hline Foraging activity $^{7}$ & $69 \pm 2^{\mathrm{a}}$ & $87 \pm 4^{\mathrm{b}}$ & $70 \pm 3^{\mathrm{a}}$ & $87 \pm 7^{\mathrm{b}}$ \\
\hline Queen distribution ${ }^{8}$ & $37 \pm 3^{\mathrm{a}}$ & $37 \pm 2^{\mathrm{a}}$ & $37 \pm 1^{\mathrm{a}}$ & $38 \pm 2^{\mathrm{a}}$ \\
\hline Distribution of larvae $^{9}$ & $33 \pm 0^{\mathrm{a}}$ & $37 \pm 2^{\mathrm{ab}}$ & $35 \pm 1^{\mathrm{a}}$ & $41 \pm 1^{\mathrm{b}}$ \\
\hline \multicolumn{5}{|c|}{ Different letters indicate statistically significant differences between supercolonies (GLM analysis, Tukey's post hoc test, P $<0.05$ ) } \\
\hline \multicolumn{5}{|c|}{${ }^{1}$ Index of interspecific aggression } \\
\hline \multicolumn{5}{|l|}{$2 \%$ of fights initiated } \\
\hline \multicolumn{5}{|c|}{$3 \%$ of fights won during intraspecific one-on-one tests } \\
\hline \multicolumn{5}{|c|}{${ }^{4}$ Number of workers outside after $10 \mathrm{~min}$ (without food) } \\
\hline \multicolumn{5}{|c|}{5 Number of chambers visited by workers during the $10 \mathrm{~min}$ of exploration } \\
\hline \multicolumn{5}{|c|}{6 Time to food detection (s) } \\
\hline \multicolumn{5}{|c|}{7 Number of workers outside after 15 min (with food) } \\
\hline \multicolumn{5}{|c|}{$8 \%$ of available tubes containing queens } \\
\hline $9 \%$ of available tubes contai & & & & \\
\hline
\end{tabular}

nine behavioral traits (Fig. 1). The first principal component included aggressiveness towards allospecifics (bioassay 1), fight initiation (bioassay 2), exploration of a novel environment and the number of chambers explored (bioassay 3), time to food detection and level of foraging activity (bioassay 4) and, distribution of queens and distribution of larvae (bioassay 5). The second principal component included fight success (bioassay 2). The Spearman correlation tests detected significant relationships among behaviors forming the first component, which confirms the existence of a complex behavioral syndrome in L. humile (Fig. 2; Table 3).

These results mean that the MAIN supercolony that readily explored novel environments and demonstrated higher levels of foraging activity, was the most aggressive, and detected the food source more rapidly. In contrast, BA1 and CATA supercolonies that less readily explored novel environments, demonstrated lower levels of foraging activity, detected the food source more slowly and were less aggressive. These correlated behaviors define a proactive-reactive syndrome in $L$. humile where ants from the MAIN supercolony were proactive and both CATA and BA1 were reactive (Fig. 2; Table 3). BA2 ants were intermediate along this behavioural gradient.

\section{Discussion}

The MAIN supercolony's personality is consistent with its high degree of invasiveness. In contrast, the Catalonian supercolony, which occupies a much smaller distribution area, was less aggressive and less active. The recent emergence of the concept of behavioural syndrome has stressed the importance of within-species group-personality in collective behaviour and group performance (Webster and Ward 2011). Invasive ants, for example, are accustomed to move to new nest sites when perturbations occur. The speed and accuracy of nest relocation, assumed to contribute to their ecological success (Holway et al. 2002), are influenced by the behavioural type of the group (Hui and Pinter-Wollman 2014). Here, the MAIN supercolony's aggressiveness and its tendency to explore novel environments and scatter larvae may increase its competitive ability, to the detriment of native species or other supercolonies. One hypothesis 
Table 2 Results of the GLM analysis to characterise behavioural variation among supercolonies

\begin{tabular}{|c|c|c|c|}
\hline Colony pairs & df & $\mathrm{Z}$ & $P$ \\
\hline \multicolumn{4}{|c|}{ Interspecific aggression $^{\mathrm{a}}$} \\
\hline MAIN-CATA & 39 & 5.04 & 0.0001 \\
\hline MAIN-BA1 & 29 & 4.04 & 0.0001 \\
\hline MAIN-BA2 & 29 & 3.29 & 0.005 \\
\hline CATA-BA1 & 29 & 0.51 & 0.95 \\
\hline CATA-BA2 & 29 & -0.84 & 0.83 \\
\hline BA1-BA2 & 19 & -1.14 & 0.65 \\
\hline \multicolumn{4}{|c|}{ Intraspecific fights initiated $^{\mathrm{b}}$} \\
\hline MAIN-CATA & 95 & 3.17 & 0.008 \\
\hline MAIN-BA1 & 71 & 2.61 & 0.04 \\
\hline MAIN-BA2 & 71 & 1.37 & 0.52 \\
\hline CATA-BA1 & 71 & 0.01 & 1 \\
\hline CATA-BA2 & 71 & -1.32 & 0.55 \\
\hline BA1-BA2 & 47 & -1.14 & 0.66 \\
\hline \multicolumn{4}{|c|}{ Exploratory activity $^{\mathrm{c}}$} \\
\hline MAIN-CATA & 19 & 6.51 & 0.0001 \\
\hline MAIN-BA1 & 14 & 5.07 & 0.0001 \\
\hline MAIN-BA2 & 14 & 2.94 & 0.02 \\
\hline CATA-BA1 & 14 & -0.05 & 0.99 \\
\hline CATA-BA2 & 14 & -2.43 & 0.07 \\
\hline BA1-BA2 & 9 & -2.02 & 0.18 \\
\hline \multicolumn{4}{|l|}{ Food detection $^{\mathrm{d}}$} \\
\hline MAIN-CATA & 19 & -5.15 & 0.0001 \\
\hline MAIN-BA1 & 14 & -4.68 & 0.0001 \\
\hline MAIN-BA2 & 14 & -2.6 & 0.04 \\
\hline CATA-BA1 & 14 & -0.16 & 0.99 \\
\hline CATA-BA2 & 14 & 2.31 & 0.09 \\
\hline BA1-BA2 & 9 & -2.2 & 0.12 \\
\hline \multicolumn{4}{|l|}{ Foraging activity } \\
\hline MAIN-CATA & 19 & 4.32 & 0.0001 \\
\hline MAIN-BA1 & 14 & 3.76 & 0.0001 \\
\hline MAIN-BA2 & 14 & 0.08 & 0.99 \\
\hline CATA-BA1 & 14 & 0.31 & 0.99 \\
\hline CATA-BA2 & 14 & -3.52 & 0.002 \\
\hline BA1-BA2 & 9 & -3.25 & 0.006 \\
\hline \multicolumn{4}{|c|}{ Distribution of larvae $^{\mathrm{f}}$} \\
\hline MAIN-CATA & 19 & 3.92 & 0.0001 \\
\hline MAIN-BA1 & 14 & 4.24 & 0.0001 \\
\hline MAIN-BA2 & 14 & 2.1 & 0.15 \\
\hline CATA-BA1 & 14 & 1.22 & 0.7 \\
\hline CATA-BA2 & 14 & -1.1 & 0.7 \\
\hline
\end{tabular}

Table 2 continued

\begin{tabular}{llll}
\hline Colony pairs & df & $\mathrm{Z}$ & $P$ \\
\hline BA1-BA2 & 9 & -1.92 & 0.24 \\
\hline
\end{tabular}

The dependent variables were the nine measures of behaviour. The independent variable was the colony (fixed categorical factor with four levels: BA1, BA2, Main, and Cata). We only report results for the six behaviours for which the four supercolonies differed

Significant results are in bold $(P<0.05)$

${ }^{\mathrm{a}}$ Index of interspecific aggression (MAIN and CATA $\mathrm{n}=20$; $\mathrm{BA} 1$ and $\mathrm{BA} 2 \mathrm{n}=10$ )

${ }^{b} \mathrm{~N}$ of fights initiated (MAIN and CATA $\mathrm{n}=48$; BA1 and BA2 $\mathrm{n}=24$ )

c $\mathrm{N}$ of workers outside after $10 \mathrm{~min}$ (without food) (MAIN and CATA $\mathrm{n}=10$; BA1 and BA2 $\mathrm{n}=5$ )

d Time to food detection (MAIN and CATA $\mathrm{n}=10$; BA1 and BA2 $\mathrm{n}=5$ )

e $\mathrm{N}$ of workers foraging during 15-min period (with food) (MAIN and CATA $\mathrm{n}=10 ;$ BA1 and BA2 $\mathrm{n}=5$ )

f $\%$ of available tubes containing larvae (MAIN and CATA $\mathrm{n}=10 ; \mathrm{BA} 1$ and BA2 $\mathrm{n}=5$ )

to explain the success of invasive ants is the violation of the discovery-dominance trade-off in native ant communities (Holway 1999). This trade-off implies that some species are exploitative specialists, while others are interference specialists. We observed here that the MAIN supercolony is better at both discovering and dominating the resources than the other supercolonies. Such competitive advantage over both other supercolonies and local ant species (Holway 1999) may provide a direct mechanism of its invasion success. Our results concur with those of a previous study that compared aggressiveness in the two European supercolonies (Abril and Gómez 2010). This polymorphism in personality traits among native and invasive populations raises interesting questions regarding the evolutionary processes underlying this behavioural pattern. Two non-exclusive hypotheses may be proposed.

First, either evolutionary processes-such as founder effects (Tsutsui et al. 2000) or selection for highly adaptive behaviour (Giraud et al. 2002)—or high levels of phenotypic plasticity (Chown et al. 2007) might account for behavioural differences between populations across biogeographic ranges. For 


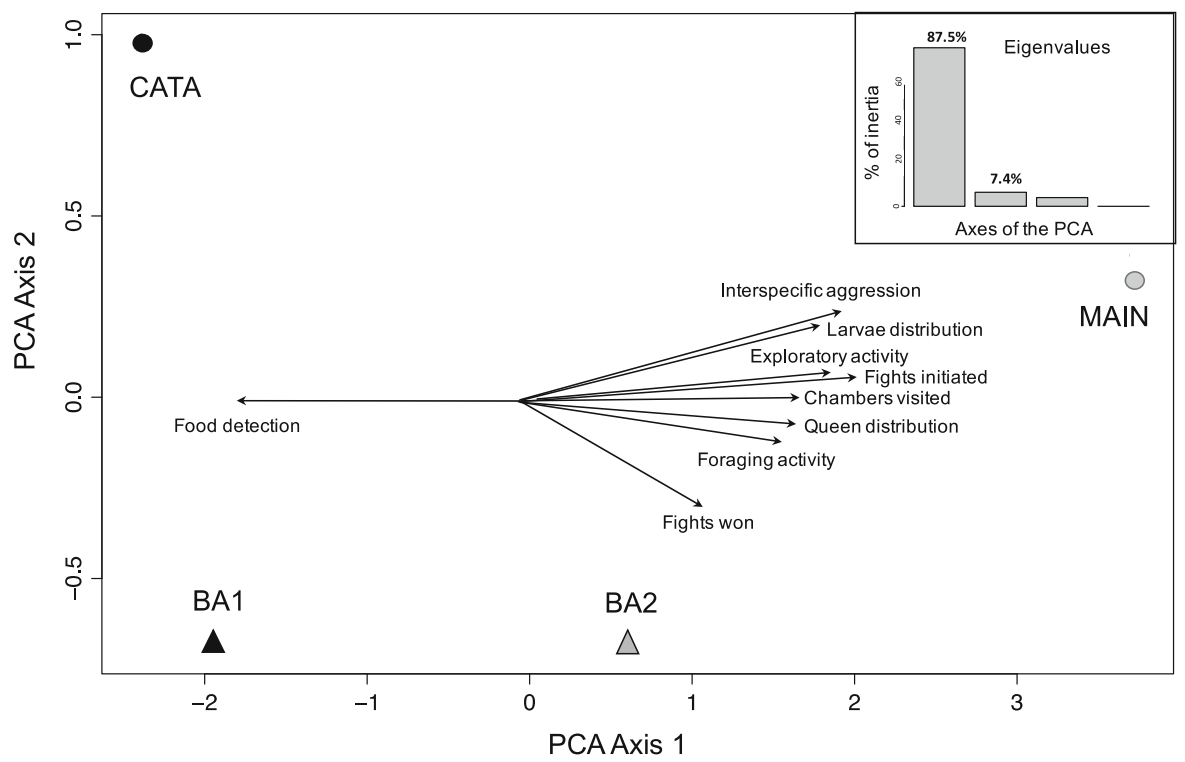

Fig. 1 PCA biplot along the two principal components; associating supercolonies with nine behaviours. In the upper right corner, the percentage of the inertia of the first axes of the principal component analysis is given in an eigenvalues plot. PC1 and PC2 accounted for 87 and $8 \%$ of the total variance in the nine behavioral traits

Table 3 Correlations between the behaviours in the experiments using native and introduced Argentine ant supercolonies

\begin{tabular}{lllll}
\hline & Exploratory activity & Foraging activity & Chambers visited & Food detection \\
\hline Foraging activity & $\mathbf{0 . 6 4}$ & - & & - \\
Chambers visited & 0.25 & 0.3 & $\mathbf{- 0 . 4 2}$ & - \\
Food detection & $\mathbf{- 0 . 7 2}$ & $\mathbf{- 0 . 5 2}$ & \\
\hline
\end{tabular}

Significant correlations are in bold (Spearman's $\mathrm{r}, P<0.05$ )

example, island and mainland populations of the European common frog, Rana temporaria display clear differences in their behaviour; island populations are bolder and more explorative than populations from the mainland (Brodin et al. 2013). Similarly, native and introduced populations of the invasive crayfish, Pacifastacus leniusculus, differ in a series of behavioural traits (Pintor et al. 2008; Pintor and Sih 2009). In the case of the Argentine ant, we expected to find a behavioural type specific to each range. Instead of a binary pattern, however, Argentine ant supercolonies display a behavioural continuum that is not influenced by geographic origin (native/introduced range). There are less active, less aggressive supercolonies (the Catalonian supercolony in the introduced range and BA1 in the native range) and highly active and aggressive supercolonies (the MAIN supercolony in the introduced range). The BA2 (native) supercolony is intermediate along this behavioural continuum.
Second, colony-level variation in behavioural type may be inherent to native populations and maintained after introduction events. In support of this argument, although the two native supercolonies (BA1 and BA2) were located only $1 \mathrm{~km}$ apart, they were not behaviourally similar to each other; BA1 workers showed a greater resemblance to workers from the Catalonian supercolony than to BA2 workers. Interestingly, these two supercolonies differ in size, BA1 and BA2 range over 6 and 11 ha respectively. It seems that the personality polymorphism is also related to differences in group's success in the native range, because BA2 has the greater range and the more aggressive personality. Differences in supercolonies' age might be an alternative explanation for differences in spatial occupation. However, despite multiple surveys, they both have been detected in late 2000 s (Josens R; Pers. Comm.), suggesting that they are of a similar age. Group-level personalities are known from 

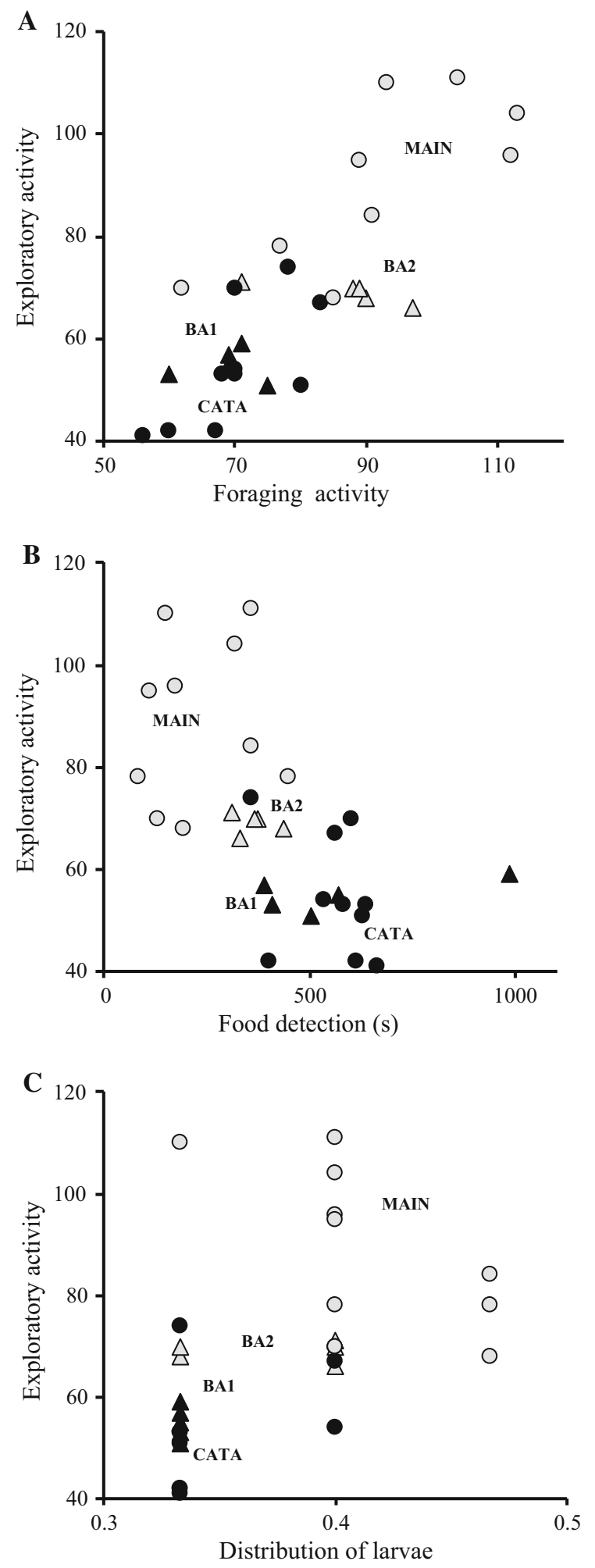

4Fig. 2 Statistically significant correlations between personality traits in Argentine ant supercolonies. a Exploratory activity and foraging activity $(\mathrm{r}=0.64 ; \mathrm{P}<0.05) ; \mathbf{b}$ exploratory activity and food detection $(\mathrm{r}=-0.72 ; \mathrm{P}<0.05)$. See Table 1 for behavioural scores details. Behaviours were quantified using workers from four different supercolonies: from the introduced range, MAIN (grey circles) and CATA (black circles), and from the native range, BA1 (black triangles) and BA2 (grey circles)

many taxa (Webster and Ward 2011). This very exciting topic has also received recent attention in social insects research (Jandt et al. 2014). Previous studies described differences in colony-personality within non-invasive species suggesting that differences in colony-personality are the rule rather than the exception in ants. Our study confirms these findings adding for the first-time group-personality data on populations from the native and introduced ranges of an invasive ant species.

Invasive ants often demonstrate a shift in social organisation, forming supercolonies that extend over hundreds of kilometres (Tsutsui et al. 2000; Giraud et al. 2002; Vogel et al. 2010; Blight et al. 2012), that contributes to their ecological success. In addition to this post-invasion evolution, our results suggest that Argentine ant supercolonies follow a pre-adaptation invasion scenario, with the ability to invade new areas occurring before long-distance dispersal. The ecological success of the Argentine ant could be explained by specific phenotypes that already exist in the native range, in certain supercolonies. The behavioural type harboured by workers from such supercolonies may be important for overcoming the different stages of the invasion process. To test this hypothesis, data from additional native and introduced populations of other invasive ant species are needed; they should be coupled with a phylogenetic analysis that provides information on supercolony relatedness.

Our study constitutes a first important step in the study of colony-personality polymorphism in invasive ant species. Understanding the underlying mechanisms responsible for the maintenance of such phenotypic polymorphism is key issue that deserves to be thoroughly investigated. Behaviour is crucial for understanding how animals respond to environmental changes when they move out of their native ranges (Chapple et al. 2012). Differences in group personalities 
may facilitate the persistence and invasion of animals under novel selective pressures by promoting adaptive behaviours relevant to their ecology such as higher aggressiveness and exploratory activity. Natural selection may favour certain behaviours over others when animals are confronted with different ecological challenges posed by their introduction to new biogeographic regions. Therefore, we stress the necessity of taking the concept of animal personality into account when addressing the issue of invasive species.

Acknowledgements We thank Phil Lester and two anonymous reviewers for their helpful comments on the earlier version of the manuscript. This work was funded by the Fyssen Foundation (postdoctoral contract to OB), the Spanish Ministry of Economy and Competitiveness, and the European Regional Development Fund (project CGL201236181 to XC and RB). We thank Mrs Jessica Pearce for her English editing services.

\section{References}

Abril S, Gómez C (2010) Aggressive behaviour of the two European Argentine ant supercolonies (Hymenoptera: formicidae) towards displaced native ant species of the northeastern Iberian Peninsula. Myrmecol News 14:99-106

Aplin LM, Farine DR, Morand-Ferron J et al (2013) Individual personalities predict social behaviour in wild networks of great tits (Parus major). Ecol Lett 16:1365-1372. doi:10. 1111/ele. 12181

Aplin LM, Farine DR, Mann RP, Sheldon BC (2014) Individuallevel personality influences social foraging and collective behaviour in wild birds. Proc R Soc Lond B 281:20141016. doi:10.1098/rspb.2014.1016

Bengston SE, Dornhaus A (2014) Be meek or be bold? A colony-level behavioural syndrome in ants. Proc R Soc B Biol Sci 281:20140518. doi:10.1098/rspb.2014.0518

Blight O, Berville L, Vogel V et al (2012) Variation in the level of aggression, chemical and genetic distance among three supercolonies of the Argentine ant in Europe. Mol Ecol 21:4106-4121

Blight O, Albet Diaz-Mariblanca G, Cerda X, Boulay R (2016) A proactive-reactive syndrome affects group success in an ant species. Behav Ecol 27:118-125. doi:10.1093/beheco/ $\operatorname{arv} 127$

Brandt M, van Wilgenburg E, Tsutsui ND (2009) Global-scale analyses of chemical ecology and population genetics in the invasive Argentine ant. Mol Ecol 18:997-1005. doi:10. 1111/j.1365-294X.2008.04056.x

Brodin T, Lind MI, Wiberg MK, Johansson F (2013) Personality trait differences between mainland and island populations in the common frog (Rana temporaria). Behav Ecol Sociobiol 67:135-143. doi:10.1007/s00265-012-1433-1

Carere C, Gherardi F (2013) Animal personalities matter for biological invasions. Trends Ecol Evol 28:5-6. doi:10. 1016/j.tree.2012.10.006
Chapman BB, Thain H, Coughlin J, Hughes WOH (2011) Behavioural syndromes at multiple scales in Myrmica ants. Anim Behav 82:391-397. doi:10.1016/j.anbehav.2011.05. 019

Chapple DG, Simmonds SM, Wong BBM (2012) Can behavioral and personality traits influence the success of unintentional species introductions? Trends Ecol Evol 27:57-62. doi:10.1016/j.tree.2011.09.010

Chown SL, Slabber S, McGeouch M et al (2007) Phenotypic plasticity mediates climate change responses among invasive and indigenous arthropods. Proc Biol Sci 274:2531-2537. doi:10.1098/rspb.2007.0772

Clavero M, García-Berthou E (2005) Invasive species are a leading cause of animal extinctions. Trends Ecol Evol 20:110. doi:10.1016/j.tree.2005.01.003

Cote J, Fogarty S, Weinersmith K et al (2010) Personality traits and dispersal tendency in the invasive mosquitofish (Gambusia affinis). Proc Biol Sci 277:1571-1579. doi:10. 1098/rspb.2009.2128

Dyer JRG, Croft DP, Morrell LJ, Krause J (2009) Shoal composition determines foraging success in the guppy. Behav Ecol 20:165-171. doi:10.1093/beheco/arn129

Fogarty S, Cote J, Sih A (2011) Social personality polymorphism and the spread of invasive species: a model. Am Nat 177:273-287. doi:10.1086/658174

Giraud T, Pedersen JS, Keller L (2002) Evolution of supercolonies: the Argentine ants of southern Europe. Proc Natl Acad Sci USA 99:6075-6079. doi:10.1073/pnas. 092694199

Gordon DM, Guetz A, Greene MJ, Holmes S (2011) Colony variation in the collective regulation of foraging by harvester ants. Behav Ecol 22:429-435. doi:10.1093/beheco/ $\operatorname{arq} 218$

Helanterä H, Strassmann JE, Carrillo J, Queller DC (2009) Unicolonial ants: where do they come from, what are they, and where are they going? Trends Ecol Evol 24:341-349. doi:10.1016/j.tree.2009.01.013

Holway DA (1999) Competitive mechanisms underlying the displacement of native ants by the invasive Argentine ant. Ecology 80:238-251

Holway DA, Suarez AV (1999) Animal behavior: an essential component of invasion biology. Trends Ecol Evol 14:328-330. doi:10.1016/S0169-5347(99)01636-5

Holway DA, Lach L, Suarez AV et al (2002) The causes and consequences of ant invasions. Annu Rev Ecol Syst 33:181-233. doi:10.1146/annurev.ecolsys.33.010802. 150444

Hui A, Pinter-Wollman N (2014) Individual variation in exploratory behaviour improves speed and accuracy of collective nest selection by Argentine ants. Anim Behav 93:261-266. doi:10.1016/j.anbehav.2014.05.006

Jandt JM, Bengston S, Pinter-Wollman N et al (2014) Behavioural syndromes and social insects: personality at multiple levels. Biol Rev 89:48-67. doi:10.1111/brv.12042

Keiser CN, Jones DK, Modlmeier AP, Pruitt JN (2014) Exploring the effects of individual traits and within-colony variation on task differentiation and collective behavior in a desert social spider. Behav Ecol Sociobiol. doi:10.1007/ s00265-014-1696-9

Kleeberg I, Pamminger T, Jongepier E et al (2014) Forewarned is forearmed: aggression and information use determine 
fitness costs of slave raids. Behav Ecol 25:1058-1063. doi:10.1093/beheco/aru084

Kralj-Fišer S, Schuett W (2014) Studying personality variation in invertebrates: why bother? Anim Behav 91:41-52. doi:10.1016/j.anbehav.2014.02.016

Lowe S, Browne M, Boudjelas S, De Poorter M (2000) 100 of the world's worst invasive alien species: a selection from the global invasive species database. Invasive Species Specialist Group, Auckland, p 12

Modlmeier AAP, Keiser CN, Shearer TA, Pruitt JN (2014) Species-specific influence of group composition on collective behaviors in ants. Behav Ecol Sociobiol 68:1929-1937. doi:10.1007/s00265-014-1799-3

Mooney HA, Cleland EE (2001) The evolutionary impact of invasive species. Proc Natl Acad Sci USA 98:5446-5451. doi:10.1073/pnas.091093398

Pinter-Wollman N, Gordon DM, Holmes S (2012) Nest site and weather affect the personality of harvester ant colonies. Behav Ecol 23:1022-1029. doi:10.1093/beheco/ars066

Pintor LM, Sih A (2009) Differences in growth and foraging behavior of native and introduced populations of an invasive crayfish. Biol Invas 11:1895-1902. doi:10.1007/ s10530-008-9367-2

Pintor LM, Sih A, Bauer ML (2008) Differences in aggression, activity and boldness between native and introduced populations of an invasive crayfish. Oikos 117:1629-1636. doi:10.1111/j.1600-0706.2008.16578.x

Pruitt JN, Keiser CN (2014) The personality types of key catalytic individuals shape colonies' collective behaviour and success. Anim Behav 93:87-95. doi:10.1016/j.anbehav. 2014.04.017

Sakai AK, Allendorf FW, Holt JS et al (2001) The population biology of invasive species. Annu Rev Ecol Syst 32:305-332

Scharf I, Modlmeier AP, Fries S et al (2012) Characterizing the collective personality of ant societies: aggressive colonies do not abandon their home. PLoS One 7:1-7. doi:10.1371/ journal.pone.0033314

Sih A, Bell A, Johnson JC (2004) Behavioral syndromes: an ecological and evolutionary overview. Trends Ecol Evol 19:372-378. doi:10.1016/j.tree.2004.04.009
Simberloff D, Martin JL, Genovesi P et al (2013) Impacts of biological invasions: what's what and the way forward. Trends Ecol Evol 28:58-66. doi:10.1016/j.tree.2012.07. 013

Suarez AV, Holway DA, Case TJ (2001) Patterns of spread in biological invasions dominated by long-distance jump dispersal: insights from Argentine ants. PNAS 98:1095-1100. doi:10.1073/pnas.98.3.1095

Thomas ML, Payne-Makrisa CM, Suarez AV, Tsutsui ND, Holway DA (2006) When supercolonies collide: territorial aggression in an invasive and unicolonial social insect. Mol Ecol 15:4303-4315. doi:10.1111/j.1365-294X.2006.03038.x

Tsutsui ND, Suarez AV, Holway DA, Case TJ (2000) Reduced genetic variation and the success of an invasive species. Proc Natl Acad Sci USA 97:5948-5953. doi:10.1073/pnas. 100110397

van Wilgenburg E, Torres C, Tsutsui ND (2010) The global expansion of a single ant supercolony. Evol App 3:136-143. doi:10.1111/j.1752-4571.2009.00114.x

Vogel V, Pedersen JS, Giraud T et al (2010) The worldwide expansion of the Argentine ant. Divers Distrib 16:170-186. doi:10.1111/j.1472-4642.2009.00630.x

Webster MM, Ward AJW (2011) Personality and social context. Biol Rev Camb Philos Soc 86:759-773. doi:10.1111/j. 1469-185X.2010.00169.x

Wolf M, Weissing FJ (2012) Animal personalities: consequences for ecology and evolution. Trends Ecol Evol 27:452-461. doi:10.1016/j.tree.2012.05.001

Wray MK, Seeley TD (2011) Consistent personality differences in house-hunting behavior but not decision speed in swarms of honey bees (Apis mellifera). Behav Ecol Sociobiol 65:2061-2070. doi:10.1007/s00265-011-1215-1

Wray MK, Mattila HR, Seeley TD (2011) Collective personalities in honeybee colonies are linked to colony fitness. Anim Behav 81:559-568. doi:10.1016/j.anbehav.2010.11. 027

Wright CM, Keiser CN, Pruitt JN (2015) Personality and morphology shape task participation, collective foraging and escape behaviour in the social spider Stegodyphus dumicola. Anim Behav 105:47-54. doi:10.1016/j.anbehav. 2015.04.001 